\title{
Speaking Truth to Power: How and Why Cathedrals Touch Lives
}

\author{
Ivor Moody \\ Vice Dean and Canon Pastor, Chelmsford Cathedral, Essex, The United Kingdom
}

Email address:

ivor.moody@chelmsfordcathedral.org.uk

\section{To cite this article:}

Ivor Moody. Speaking Truth to Power: How and Why Cathedrals Touch Lives. International Journal of Literature and Arts. Vol. 9, No. 4, 2021, pp. 193-196. doi: 10.11648/j.ijla.20210904.18

Received: July 19, 2021; Accepted: August 7, 2021; Published: August 18, 2021

\begin{abstract}
In an age where cathedrals continue to attract and inspire many, a powerful, persuasive argument for their success story is often cited in their beauty, grandeur, independence and immense historical and architectural importance. With great power though comes great responsibility and the temptation for its misuse, for which cathedrals by virtue of their size, status and spheres of influence are particularly susceptible. This article attempts a re-evaluation of the source of that power. Through a reflection on personal experience, an exploration of liturgy and a theological assessment of the relationship between the border and the centre, it recalls the Gospel imperative that real power resides in the first being last, and the Kingdom of God belonging to the poor. It argues that the very thing which gives the cathedral its authority, influence and responsibility- the cathedra- concerns the frailty and vulnerability of a bishop which, through her apostolic ministry centered and emanating from the 'mother church', brings true meaning and relevance to the cathedrals' task of drawing alongside and giving theological and spiritual meaning to people's own frailty, vulnerability and pain. It concludes with the suggestion that, consequently, cathedrals can be places which envelop all of us.
\end{abstract}

Keywords: Cathedral, Power, Cathedra, Borders, Vulnerability, Sinfulness, Powerlessness, Liturgy

\section{Introduction}

Cathedrals get under your skin. Perhaps some of the strongest evidence for this is the fact that, statistically, attendance figures have defied the decline in church attendance reported elsewhere in the Church of England. In contrast to a fall by approximately three hundred thousand since 2009, cathedrals reported a total of thirty-seven thousand people worshipping each week in 2018, an increase of fourteen per cent over the past ten years.[1] Visitor numbers of just over ten million in 2018 were the highest ever recorded.

The reasons cited for this picture of growth are various and numerous, but perhaps we may say that, above all, from the earliest cathedrals down to the most recent ones, they have 'Entered the English psyche and taken up residence in the English soul'. [2] This phenomenon of growth has been accompanied by considerable and sustained scholarship on the nature and theology of cathedrals which was given impetus in 1994 with the thorough and wide ranging report and recommendations on cathedral life and governance by the Archbishop's Commission Report 'Heritage and Renewal'. [3] The report has excited nearly three decades of further writing and reflection, and notably another influential report published in 2012 called 'Spiritual Capital. The Presence of English Cathedrals' which argued for cathedral's comprehensive contribution to faith and societal upbuilding. [4]

Against this background of growth and successful outreach, what follows is not something which is counter-cultural or adversarial to all that, but a reflection on something which lies at the heart of and is the raison d'etre for cathedralssomething indeed which gives them their name and purposewhich seems not to have featured much in all the ensuing scholarship, but which might be one of the most prescient reasons why cathedrals are so important and relevant for corporate and individual existence.

\section{A View from the Edge}

There was once a man who sat crying on a bench outside Chelmsford Cathedral. One of the day chaplains sat with him. 
A heart wrenching story unfolded about a disabled son, a diagnosis of cancer and a fear of not being able to cope with a future that now seemed too fearful to contemplate. 'I'm not a Christian,' said the man. 'So, I didn't feel I could come into the cathedral'. What was missing from this statement was why he had come even there, to the very border of the cathedral, to the threshold of sacred space, to be on the outside looking in, to cry and to reflect in the shadow of this 'serious place standing on serious earth'. [5]

The French philosopher and mystic Simone Weil said that her lifelong ambition was to stand at the intersection of Christians and non-Christians, never to enter upon the church and so be enabled independently, prophetically and positively to reflect upon its significance. The mere presence of an 'outsider', someone for whom a border was both a place of safety but also a barrier, a closed portal to a forbidden place and a community to which he considered he didn't and couldn't belong, can reveal much about where the power and the powerlessness of cathedrals lies, and how that might be significant for today's postmodern, 'believing without belonging' generation. [6]

Cathedrals themselves have been described as border dwellers, standing on the divide between the religious and the secular worlds. Too often though the temptation has been to use this position to promote the powerfulness of cathedrals, lauding their status as standing over and against the secular world and superior to it, their size, beauty and space compensating for that which cannot be found or experienced in everyday life. They have been described as impersonal, anonymous spaces, their power and influence residing precisely in the acceptance and encouragement of a lack of commitment and a sense of belonging without undue pressure to contribute or to conform. In recent years it is a view which has been fuelled by the debate over entry charging, which for many has caused an intellectual, psychological juggling act trying to reconcile a powerhouse of prayer and the powerful influence of a hugely important historical monument and its maintenance and presence for future generations.

The argument for a primary seat of power of cathedrals which resides in their immensity, beauty and history is a persuasive one. Their capacity for transcendence is huge, leading their congregations and visitors into a state of timelessness, moments of escape from the chaos and urbanity of ordinary existence. To seize the self and transport it into a realm where the love of control and self-determination cherished as the mantra for modern, secular living is suspended in favour of a vastly wider and deeper truth. A world where, as Mark Rylands argues, the march of secularization is now so all-consuming that even the church itself has become complicit in the denial of the supernatural. [7] Cathedrals have a unique potential to re-connect humanity with the rich, mystical symbolism for which it struggles any more to find a language and to re-establish a transcendent link with the presence of the divine. Simon Oliver calls it the operation of the 'porous self', where one does not seize but is seized by something with a depth and a meaning beyond human control. [8] Recent surveys into a variety of cathedral experience, life and worship has revealed not only that for a significant proportion of people from two cathedrals surveyed they were attracted through worship more to mystery than dogma, to a spiritual rather than a doctrinal experience, but that perhaps even more significantly for the attendees of one cathedral between $35 \%$ and $41 \%$, even though they had not come seeking any spirituality or emotional involvement, as a result of their experience nevertheless had left with a sense of the presence of 'the other' [9].

\section{Looking over the Wall}

But what if none of these things constituted the primary seat of power of cathedrals? What if, by contrast, the source of a cathedral's influence was not its physical, aesthetic and spiritual muscle but instead its vulnerability and sinfulness? In a chapter which otherwise argues persuasively for the seductive energy of cathedrals which dwarf the self with their antiquity, grandeur and their interpretation and promotion of a 'cosmic religion', placing it within the awesome unknowability of the Universe and connecting it with history and time, Angela Tilby recognizes nevertheless that with power comes corruptibility. The very size of cathedrals allows for the presence and projection of both good and evil, and both are contained and need to be accommodated within its walls. [10]

Borders can be dangerous places. They are often theatres of confrontation, violence and fear, places where hard questions are asked and where the seemingly intractable, unanswerable conundrums of life are faced and experienced. They are places where power and powerlessness, where grandeur and transience come face to face. The man sitting weeping in the cathedral precincts and close to its entrance is symbolic of a via media, a middle way which cathedrals must navigate; between their beautiful situatedness and the frontiers of social distress; between their sublime permanence and those whose journeys are full of uncertainty and pain. Visitors to The Brandenburg Gate in Berlin come across a non-denominational 'Room of Silence' just metres from a former border which for years stood as a testimony to the evils of segregation and violence. It holds within itself both a celebration of change and transformation and a place to reflect and to grieve. In so doing it encapsulates the deepest human emotions of remembrance, joy, shame and sheer non-comprehension.

Without question the most important thing which gives cathedrals their distinctiveness from the parish churches around them is that they house the Cathedra, the Bishop's seat. And the presence and power of episcopal ministry is defined by the challenges and demands of what it might mean for a cathedral to be a 'border community'. It is an apostolic, prophetic and theological ministry centered on justice, empowerment, prayer and pastoral care. [11] It takes cathedrals to the heart of civic and political communities in their task to energize compassion and righteous action, at a 
county and national level as opposed to a merely parochial one, often for the most disempowered and vulnerable in our societies.

And yet at the outset one of the most important and precious gifts which a bishop brings to her cathedral is her own vulnerability and sinfulness. They are built into the service of the ordination and consecration of a bishop. There is the recognition that human fallibility lies at the heart of the conferment of authority and power, and that the potential for a misused capacity for powerfulness can compound the powerlessness of others. 'Give her humility' prays the archbishop over the ordinand, 'That she may use her authority to heal, not to hurt; to build up, not to destroy'. A further warning ensues about the burden of high office which is around the struggle for stamina and strength as much as it is about responsibility: 'You cannot bear the weight of this calling in your own strength' warns the archbishop, 'But only by the grace and power of God'. [12]

Every year at the Chrism Mass on Maundy Thursday at Chelmsford Cathedral it is a young child who stands in front of the bishops and asks them 'Will you continue faithfully in this ministry?' At this moment the contrast between power and humility is stark, and a reminder that entry into the Kingdom of Heaven is predicated upon an acceptance and understanding of powerlessness. At the service of welcome in the cathedral for the new Bishop of Chelmsford in 2021, four children from across the Diocese incorporating Essex and East London had the following dialogue with the new bishop: Child: We greet you in the name of Christ. Who are you and why do you request entry?

The bishop: I am Guli, a servant of Jesus Christ, and I come as one seeking the grace of God, to travel with you in faith and service.

Child: Why have you been sent to us?

The bishop: I am sent as your Diocesan bishop, to proclaim the love of Christ and with you to worship God with heart and soul, mind and strength.

Child: How do you come among us and with what confidence?

The bishop: I come in weakness and vulnerability, confident only in Jesus Christ, crucified and risen.

Child: Let us then humble ourselves together, enter the house of the Lord, and seek God's mercy and strength.

\section{Glimpsing a New Perspective}

It is difficult to overstate the importance of this for the cathedral and its work. From the Cathedra situated at the east end a bishop's recognition of his humility and vulnerability must radiate out and 'infect' the congregations and all who are drawn to these magnificent sacred spaces. If the cathedral is peculiarly well placed to speak to and embrace the vulnerable and those at the margins of society, then those whose consistent experience of weakness and the fear of being overwhelmed need to see that their deep acquaintance with struggle is shared and understood by those whose power resides in their choice and election to be carers of others. In the stripping away of the illusion of certainty and omnicompetence there can ensue a moment of grace, when those called to love the powerless recognize their own powerlessness which is both a realization of a shared complicity in sinfulness and the existence of their own 'lovableness'.

Viewing the Cathedra as the seat of power in this way has two major consequences. In the cathedral's task of embodying and promoting the bishop's apostolic ministry with all those qualities and requirements mentioned earlier it is a process which has little to do with privatized religion but establishes instead a collective identity. A public activity which encourages a community awareness and articulation of independence and interdependence especially in those areas of industry, unemployment and deprivation, in many cases where parish church cathedrals find themselves. A partnership where boundaries- borders- are frequently crossed and re-crossed, and which can give people whose political and social task is often difficult and weighted to earth, new vision and hope. It does all this not from a position of wealth and privilege but in its willingness and ability to come alongside people in the shared task to make life better, through a symbiotic relationship centered on the bishop himself, between grandeur and importance and openness and a recognition of transience.

And if such partnerships are explored effectively and honestly in this way, then there is a probable exposure to a lack of control and a challenging to coping which is for the cathedral congregation to own, and for our man in the cathedral churchyard it is perhaps the most precious gift of support and understanding which can be offered. The cathedral becomes a place where there are not answers but questions, and a safe space within which- or in the vicinity of which- to ask them. If the civic and political communities associated with the cathedral can be offered a vision of a more hopeful future, then there is also a culture which welcomes the task of grappling with those hard societal and personal issues which affect everyone. The cathedral becomes an environment for 'ordinary theology', a phrase coined originally in 2002 by Jeff Astley, that is, a place where people can find the deepest theological expression for their questions, thoughts and feelings and pain. [13] A religious understanding of their everyday life experiences which they are enabled to comprehend not because they are required to buy into a theological dialogue obscure and impenetrable to so many, but because they find themselves empathetically and sympathetically with others affected by the same thoughts and questions, hedged about by a fragility and a vulnerability communicated directly from the cathedral itself. And as David Hoyle reminds us, awesome and mesmerizing cathedrals may be, but they emerged historically as radical, counter-cultural and challenging edifices which asked severe questions of the political, social and frequently violent environments which surrounded them. [14]

A primary vehicle for the expression of this 'powerfulness of powerlessness' for the cathedral and its congregations and visitors resides in the liturgies it can offer. Often unique in 
their scope and outreach, tailored specifically and carefully for attendees with particular causes and concerns, but also magnets for hundreds from the community who simply want to mark the change of seasons and yearly landmarks which punctuate their lives, they can be dramatic expressionsprojections- of those hard questions and difficult life decisions which would otherwise find no adequate means of expression. Ritual gatherings which 'Can take on a sacredness because we share and become involved with their joys and sorrows, their suffering and pain and life and death: those very things with which Christ is passionately concerned'. [15] They are often liturgies which have little to do with increasing church attendance, but rather they act as companions on the road to deepen faith and encouragement for the journey. A 'Red Sea' experience empathizing with people's vulnerability and pain, enabling them to cross from slavery to freedom, from darkness to light.

\section{Conclusion}

In 2018 I had the privilege of being Chaplain to the Mayor of Chelmsford. At the closing ceremony marking the end of her mayoral year a candle was given to everyone in the congregation to hold alight during the service, and then to take home as a symbol of vision and hope following all the good that had happened over the last twelve months. In the shadow of the Paschal Candle I said this:

'If you think that your weakness, your vulnerability, your inadequacy makes you poor subjects for the great task of service that awaits you then take heart, because this Easter candle is ultimately a symbol of God's vulnerability. How much more of an impossible dream could there be, how greater a bringing together of opposites could there be than the violence and finality of Good Friday being met and greeted by the merest, slenderest, unlikeliest possibility of the empty tomb suggesting that death might after all not have had the final say? And yet here we are today, still creatures of hope, still creatures of promise, still human beings capable of vision, despite all that would seek to deny and destroy that. The flame that you will hold in a few minutes will be a reminder that you, we all, are brothers and sisters, part of that merest, slenderest, unlikeliest community started and shared by God himself that can and must still make a difference'.

To a man sitting weeping in the cathedral churchyard, overcome by the spectre of disability, cancer and hopelessness, at the very border of beauty and ugliness, of doubt and faith, of life and death, the power of powerlessness could be the strongest message of hope and reassurance there is, embodied by the very cathedral in whose shadow he sat. And his weeping presence is a reminder that he is all of us.

\section{References}

[1] Rachel Farmer: www.anglicannews.org/news/2019/11/churchof-england-cathedrals-continue-to-attract-increasingnumbers.aspx.

[2] Moody, I. (2018) A Contradiction in Terms? Assessing the Place and Importance of the English Parish Church Cathedrals in Modern Believing. The Journal of Theological Liberalism. Liverpool: University Press.

[3] Archbishops' Commission Report (1994) Heritage and Renewal. Archbishops' Commission on Cathedrals. London: Church House Publishing.

[4] Theos and The Grubb Institute Report (2012) Spiritual Capital. The Presence and Future of English Cathedrals. London: Theos.

[5] Larkin, P. (1954) Church Going.

[6] Davie, G. Subtitle to Religion in Britain Since 1945: Believing Without Belonging. Oxford: Blackwell.

[7] Rylands, M. (2006) Mission Shaped Cathedrals in Bayes, P. and Sledge, T. (2006) Mission Shaped Parish. London: Church House Publishing.

[8] Oliver, S. (2017) The Cathedral and Rooted Growth in Platten, S.(ed), Holy Ground. Cathedrals in the Twenty First Century. Durham: Sacristy Press.

[9] Francis, L. Annis, J. Robbins, M. (2015) The Spiritual Revolution and the Spiritual Quest of Cathedral Visitors in Francis, L. Anglican Cathedrals in Modern Life. The Science of Cathedral Studies. United States: Palgrave Macmillan.

[10] Tilby, A. (1998) The Sacred Grove in Platten, S. and Lewis, C. Flagships of the Spirit. London: Darton, Longman \& Todd.

[11] Francis, L. \& Muskett, J. (2015) Shaping Cathedral Studies: A Scientific Approach in Anglican Cathedrals in Modern Life.

[12] The Archbishop's Council (2007) Common Worship: Ordination Services. London: Church House Publishing.

[13] See Ap Sion, T. (2015) Ministry of the Cathedral Prayer Board: Studying Ordinary Prayer in Anglican Cathedrals in Modern Life.

[14] Hoyle, D. (2017) History, Heritage and Taking Time in Platten, S. (ed) Holy Ground. Cathedrals in the Twenty First Century. Durham: Sacristy Press.

[15] Moody, I. (2007) Finding Space for the Sacred in Modern Believing: Church and Society. Liverpool: The Modern Churchpeople's Union. 